\title{
PEMBIAYAAN PENYELENGARAAN PENDIDIKAN DI MADRASAH \\ (Penelitian di MTs Baabussalaam Kota Bandung)
}

\author{
Mochamad Fadlani Salam' \\ Mahmud $^{2}$ \\ Irawan $^{3}$ \\ ${ }^{123}$ Pascasarjana UIN SGD Bandung \\ Program Magister Manajemen Pendidikan Islam \\ Kampus II, Jl. Cimencrang - Panyileukan, Bandung, Jawa Barat 40292, Indonesia \\ elfadlan@gmail.com
}

\begin{abstract}
Abstrak: Sumber dana MTs Baabussalaam Kota Bandung hanya mengandalkan dari pemerintah melalui dana Bantuan Operasional Sekolah (BOS), pencairan dana BOS sering terlambat dari waktu yang telah ditetapkan. Tujuan penelitian ini untuk mengetahui pembiayaan penyelenggaraan madrasah di MTs Baabussalaaam Kota Bandung. Penelitian ini menggunakan metode studi kasus. Pengumpulan data dilakukan dengan wawancara dan studi dokumentasi. Hasil penelitian menunjukan bahwa penyelenggaraan pembiayaan pendidikan di MTs Baabussalaam Kota Bandung yaitu; penerimaan dana BOS dari pemerintah pusat dan pemerintah daerah yang diberikan secara berangsur-angsur empat kali dalam satu tahun, saat ini menjadi dua kali dalam satu tahun sesuai aturan yang berlaku. Dana yang baru diterima di Tahun 2017 sebesar Rp. Rp.206.802.500. Pengalokasian anggaran pendidikan hanya cukup diberikan untuk pembayaran honorarium bulanan guru. Siswa madrasah hanya dipungut biaya kegiatan ekstrakulikuler, namun tidak seluruhnya melakukan pembayaran (198 siswa $X$ Rp.20.000 = Rp.3.980.000). Simpulan kajian ini bahwa kebutuhan tertinggi pembiayaan pendidikan di MTs Baabussalaam Kota Bandung adalah pada pembayaran honorarium Guru Bukan Pegawai Negeri Sipil (GBPNS), perlu ada upaya peningkatan komitmen pemerintah dalam pembiayaan pendidikan sehingga mendukung semua komponen kegiatan madrasah, dan mencapai standar nasional. Waktu pencairan biaya pendidikan perlu tepat waktu sesuai dengan kalender penidikan. Agar Partisipasi orang tua dalam pembiayaan pendidikan baik, maka harus diimbangi dengan memberikan jaminan kualitas terhadap konsumen pendidikan.
\end{abstract}

Kata Kunci; Pembiayaan, Pendidikan, Madrasah

\section{PENDAHULUAN}

Isu-isu tentang ekonomi pendidikan atau pembiayaan pendidikan semakin tajam bergulir dan mendapatkan banyak perhatian dari berbagai kalangan. Lebih-lebih tentang anggaran 20\% dalam APBN (Anggaran Pendapatan Belanja Negara) dan APBD (Anggaran Pendapatan belanja Daerah) yang telah diundangkan dan terus diperjuangkan, peningkatan kesejahteraan guru dan subsidi pendidikan dalam bentuk BOS (Bantuan Operasional Sekolah), BOM (Bantuan Operasional Madrasah), atau bantuan lainnya. Tentu saja, praktik-praktik kebijakan anggaran itu selalu saja belum sesuai ideal dengan konsep dan teori pembiayaan pendidikan. Dalam perspektif makro, pembiayaan pendidikan memang tidak habis dikaji dan belum ideal dalam kenyataan. Namun dalam banyak kesempatan, para ahli manajemen selalu berusaha memberikan pendapat sesuai keahliannya dalam mengatasi kesenjangan tersebut.

Menurut J. Wiseman (1987) terdapat tiga aspek yang perlu dikaji dalam melihat apakah pemerintah perlu terlibat dalam masalah pembiayaan pendidikan: I) Kebutuhan dan ketersediaan pendidikan terkait dengan sektor pendidikan dapat dianggap sebagai salah satu alat perdagangan dan kebutuhan akan investasi dalam sumber daya manusia/human capital, 2) Pembiayaan pendidikan terkait dengan hak orang tua dan murid untuk memilih menyekolahkan 
anaknya ke pendidikan yang akan berdampak pada social benefit secara keseluruhan, 3) Pengaruh faktor politik dan ekonomi terhadap sektor pendidikan.

Dalam hal pendidikan kejuruan dan industri, M. Woodhall (1987) menjelaskan bahwa dimasa lalu pembiayaan pendidikan jenis ini ditanggung oleh perusahaan. Perusahaan memberi subsidi kepada para pekerjanya sendiri. Sekarang peran pemerintah semakin besar dalam pembiayaan ini. Hal itu disebabkan adanya kepentingan ekonomi. Artinya kebijakan man power, diharapkan dapat meningkatkan kepentingan untuk membagi biaya dan manfaat dari pendidikan ini dengan adil.

Melalui program kerja pemerintah dalam bentuk Bantuan Operasional Sekolah (BOS) untuk madrasah yang dialokasikan anggarannya oleh Direktorat Jenderal Pendidikan Islam di Kementrian Agama, diharapkan dapat meningkatkan layanan mutu pendidikan di madrasah. Kementerian Agama melalui Direktorat Jenderal Pendidikan Islam memberikan prioritas anggaran pendidikan pada madrasah agar dapat membantu anak usia sekolah bisa merasakan pendidikan yang layak di madrasah.

Namun, Bantuan Operasional Sekolah (BOS) yang dikatakan sebagai usaha untuk meningkatkan beban biaya pendidikan dalam praktiknya belum memenuhi harapan, baik dari komitmen yang berkaitan dengan mekanisme penyalurannya yang tidak sesuai dengan aturan (Lihat; Keputusan Dirjen Pendidikan Islam No.36I Thn.20I6 tentang Petunjuk Teknis BOS Pada Madrasah TA.2016), juga masih banyak sekolah atau madrasah yang belum secara efektif melaksanakan manajemen pembiayaan dengan baik sesuai dengan prinsip dan pengelolaan yang telah ditetapkan dalam RAPBS/M (Rencana Anggaran Pendapatan dan Belanja Sekolah/Madrasah), sehingga berujung pada rendahnya kualitas sekolah atau madrasah.

Madrasah Tsanawiyah Baabussalaam Kota Bandung adalah salah satu madrasah yang mengalami masalah dari praktik pembiayaan penyelenggaraan dana BOS tersebut. Berdasarkan hasil wawancara dengan Kepala MTs Baabussalaam Kota Bandung, bahwa dana BOS yang diterima oleh madrasah bersumber dari pemerintah pusat dan daerah. Penerimaan dana tersebut di tiga tahun terakhir ini selalu mengalami keterlambatan dari waktu yang telah ditetapkan. (Lihat; KUITANSI/BUKTI

PEMBAYARAN No.B.I 160/Kk.10.19/2/PP.00.I I/03/2017).

Kepala MTs Baabussalaam Kota Bandung menjelaskan bahwa sumber dana madrasah yang dipimpinnya hanya mengandalkan bantuan dari pemerintah. Memang ada dana lain yang dihimpun oleh pihak madrasah yang bersumber dari seluruh siswa (dana kegiatan eksrakulikuler), akan tetapi tidak seluruh siswa membayar. Dari Jumlah siswa sebanyak 255 orang yang terdiri dari Kelas VII 64 orang; (Laki-laki: 36 orang, Perempuan: 28 orang), Kelas VIII 96 orang (Laki-laki: 43 orang, Perempuan 53 orang), Kelas IX 95 orang (Laki-laki: 53 orang, Perempuan: 36 orang), hanya 198 orang siswa yang rutin membayar pertahun ajaran (data terlampir).

Berdasarkan permasalahan tersebut, penelitian ini ingin mengungkap bahwa, bagaimana pengalokasian anggaran biaya penyelenggaraan pendidikan dari sumber keuangan yang didapat oleh MTs Baabussalaam Kota Bandung. Adapun tujuan penelitian ini, ingin mengetahui pembiayaan penyelenggaraan di MTs Baabussalaam Kota Bandung.

\section{METODE PENELITIAN}

Sifat penelitian ini adalah penelitian deskripsi kualitatif yaitu dengan metode studi kasus. Wina Sanjaya (2013: 73) menjelaskan metode studi kasus dapat diartikan sebagai metode penelitian deskriptif untuk menjawab pemasalahan pendidikan yang mendalam dan komprehensif dengan melibatkan subjek penelitian yang terbatas sesuai jenis kasus yang diselidiki. Subjek penelitian dalam studi kasus bisa individu, kelompok, lembaga atau golongan masyarakat tertentu. Segala aspek yang berkaitan dengan berkaitan dengan kasus dianalisis secara mendalam, sehingga diperoleh generalisasi yang utuh. 
Maka, untuk menjawab permasalahan pada penelitian ini, penelitian dilakukan dengan pendekatan penelitian kualitatif, dengan metode studi kasus. Kasus yang diambil adalah pembiayaan penyelenggaraan pendidikan di madrasah, yaitu Madrasah Tsanawiyah Baabussalaam Kota Bandung.

Teknik pengumpulan data menggunakan teknik wawancara dan studi dokumentasi. Wawancara ditujukan kepada Kepala dan Bendahara MTs Baabussalaam Kota Bandung, untuk memperoleh informasi berkaitan dengan pembiayaan penyelenggaraan pendidikan.

Adapun dokumentasi yang dimaksud adalah dokumen yang berisi data-data tentang pembiayaan pendidikan di MTs Baabussalaam Kota Bandung. Bungin (201 I: I24) menjelaskan dokumentasi adalah metode pengumpulan data dengan cara mengambil data-data berupa historis, dan fakta sosial yang tersimpan dalam bahaan yang berbentuk dokumen.

\section{HASIL DAN PEMBAHASAN}

MTs Baabussalaam Kota Bandung dibawah Yayasan Pendidikan Agama Islam (YPAI) binaan Kementrian Agama. MTs Baabussalaam beralamat di Jalan KH. Wahid Hasyim (Kopo) Gg. Sukarma Blk. No.19 Kota Bandung 40232.

Berdasarkan temuan di MTs Baabussalaam Kota Bandung diketahui bahwa sumber dana pembiayaan pendidikan dimadrasah hanya bersumber dari dana BOS pusat dan dana BOS daerah. Dana yang diterima oleh madrasah mengalami perubahan pada teknis penyaluran dan pencairannya, yang semula dibagi menjadi empat tahap dalam setahun (Lihat; Keputusan Dirjen Pendidikan Islam No.36I Thn.2016 tentang Petunjuk Teknis BOS Pada Madrasah TA.2016), kini mekanismenya menjadi dua tahap dalam setahun (Lihat; Keputusan Dirjen Pendidikan Islam No.738I Thn.2016 tentang Petunjuk Teknis BOS Pada Madrasah TA.2017). Dana tahap satu yang dterima di tahun 2017 sekarang ini sebesar Rp.206.802.500. (Sumber; RKAM MTs Baabussalaam TA.2016/2017).

Nanang Fatah mengutarakan pembiayaan pendidikan merupakan jumlah uang yang dihasilkan dan dibelanjakan untuk berbagai keperluan penyelenggaraan pendidikan yang mencakup gaji guru, peningkatan profesional guru, pengadaan sarana ruang belajar, perbaikan ruang pengadaan peralatan/mobile, pengadaan alat-alat dan buku pelajaran, alat tulis kantor (ATK), kegiatan ekstrakulikuler, kegiatan pengelolaan pendidikan, dan supervisi pendidikan (Fattah 2000:23).

Penggunaan dana BOS di madrasah (MI, MTs, dan MA) harus didasarkan pada kesepakatan dan keputusan bersama antara pihak madrasah, dewan guru, dan komite madrasah. Hasil kesepakatan di atas harus dituangkan secara tertulis dalam bentuk berita acara rapat dan ditandatangani oleh peserta rapat. Dalam petunjuk teknisnya, penggunaan dana BOS MTs untuk membiayai I 3 komponen kegiatan. Dalam menggunakan dana BOS, madrasah harus memperhatikan hal-hal sebagai berikut: I) Prioritas utama penggunaan dana BOS adalah untuk kegiatan operasional madrasah; 2) Bagi madrasah yang telah menerima DAK, tidak diperkenankan menggunakan dana BOS untuk peruntukan yang sama. Sebaliknya jika dana BOS tidak mencukupi untuk pembelanjaan yang diperbolehkan ( 13 item pembelanjaan), maka madrasah dapat mempertimbangkan sumber pendapatan lain yang diterima oleh madrasah, yaitu pendapatan hibah (misalnya DAK) dan pendapatan madrasah lainnya yang sah dengan tetap memperhatikan peraturan terkait; 3) Biaya transportasi dan uang lelah bagi guru PNS yang bertugas di luar jam mengajar, harus mengikuti batas kewajaran yang ditetapkan oleh Standar Biaya Masukan Kementerian Keuangan; 4) Bagi madrasah negeri yang sudah mendapat anggaran dalam DIPA selain BOS, maka penggunaan dana BOS hanya untuk menambahkan kekurangan, sehingga tidak terjadi double accounting; 5) Batas maksimum penggunaan dana BOS untuk belanja pegawai (honor guru/tenaga kependidikan bukan PNS dan honor-honor kegiatan) pada madrasah negeri sebesar 30\% (tiga puluh persen) dari total dana BOS yang diterima oleh madrasah dalam satu tahun. Madrasah negeri boleh menggunakan dana BOS. 
Di Mts Baabussalaam Kota Bandung, pemasukan dana tahap satu ini dialokasikan untuk Guru Bukan Pegawai Negeri Sipil (GBPNS) sebanyak 22 orang di tahun 2016 pada Bulan Agustus sebesar Rp. Rp 16.583.000.00, pada Bulan September sebesar Rp.16.583.000, pada Bulan Oktober sebesar Rp.16.8088.000, pada Bulan Nopember sebesar Rp.16.838.000, pada Bulan Desember sebesar Rp.16.663.000.

Sedangkan di tahun 2017 ini pada Bulan Januari sebesar Rp.16.463.000, pada Bulan Februari sebesar Rp.16.917.000, pada Bulan Maret sebesar Rp.17.004.000, pada Bulan April sebesar Rp. I6.869.000, pada Bulan Mei sebesar Rp.16.839.000.

Menurut Kepala MTs Baabussalaam, dalam tiga tahun ajaran ini dana yang diterima pada sering kali terjadi keterlambatan, sampai pada tahun ajaran 2016/2017 sekarang ini (lihat; KUITANSI/BUKTI PEMBAYARAN No.B.II60/Kk.10.19/2/PP.00.1I/03/2017) dalam proses pencairannya tidak sesuai dengan aturan Keputusan Dirjen Pendidikan Islam No.36I Thn.20I6 tentang Petunjuk Teknis BOS Pada Madrasah TA.20I6. Disamping itu, dana yang diterima tidak mencukupi untuk memenuhi kebutuhan komponen-komponen yang lain yang ada di lingkungan MTs Baabussalaam Kota Bandung.

Maka dari itu, perlu adanya upaya peningkatan komitmen pemerintah dalam pembiayaan pendidikan sehingga mendukung semua komponen kegiatan madrasah, dan mencapai standar nasional. Waktu pencairan biaya pendidikan perlu tepat waktu sesuai dengan kalender penidikan.

\section{KESIMPULAN}

Adapun sumber dana yang masuk dari siswa sebagai dana kegiatan ekstrakulikuler, maka dana tersebut dialokasikan untuk kegiatan berbagai ekstra kulikuler seperti seni dan olahraraga. (wawancara bersama Kepala MTs Baabussalaam). Jumlah dana yang masuk di tahun 2017 ini untuk kegiatan ekskul tersebut adalah 198 orang siswa X Rp.20.000 = Rp.3.980.000. Dana ini juga dialokasikan untuk pemberian upah mentor guru yang mengajar kegiatan ekstra kulikuler. Namun, agar partisipasi orang tua dalam pembiayaan pendidikan baik, sepeti halnya dalam kegiatan ekskul atau program madrasah yang lain, maka harus diimbangi dengan memberikan jaminan kualitas terhadap konsumen pendidikan.

\section{DAFTAR PUSTAKA}

Bungin, M. Burhan. Penelitian Kualitatif, Jakarta: Prenada Mediaa Grup, 201 I.

Fattah, Nanang, Ekonomi dan Pembiayaan Pendidikan. Bandung: Rosda Karya, 2000.

Pembiayaan Pendidikan, (Landasan, Teori, dan Studi Empiris), Jurnal Pendidikan Dasar, No.9, 2008.

Sanjaya, Wina, Penelitian Pendidikan; Jenis, Metode, dan Prosedur, Jakarta: Kencana Prenada Media Group, 2013. 